\title{
How Does the Child Experience the World of Things? 1
}

\author{
Martinus J. Langeveld \\ Bilthoven, the Netherlands
}

Nothing seems so clearly, so self-evidently given as "things," the stuff or objects of our world. Children apparently need only learn what the things are, and in this way something that is originally strange becomes familiar. This "strange" thing, however, continues to be the same. From the start, a chair is a chair, and it emerges, through the developmental encounters of the child, as an experienced and familiar chair. So the question of the nature of the things in the world of the child seems to be a rather unpromising theme. Moreover, is the world of the thing not merely the everyday, the ordinary, the normal world? Why should one look for problems in this one area where the world does not present any? Leave the things alone; leave them in their world and let us stay in our own!

However, the human child does not live inside the body like a snail in its shell. A human being lives in the world with his or her body. And in this manner he or she also lives with the things. This beingin-the-world is not merely a recording process; "recording" would imply "being disinterested." That, we are definitely not. On the contrary, anyone who has lived with children will attest to this. The child is not a recording apparatus. Besides, in spite of what was said above, the child does not start out to see the things and the world as strange. Rather, the world and the things in the world issue a challenge to the child. I would have had no qualms about changing the title of this essay to read "The Child in the World of the Things." No one roams through and into the world so free and unguarded as a child. As if it were a fairy-tale forest, so ventures the child into the world, lured by the charm of all that is new, unfamiliar, and pleasant. For the world seems pleasant and full of promises. Not senseless, but also not "familiar": everything seems possible, so there exists, as yet, no "non-sense" (meaninglessness).

The natural assumption that the child has about the world-that it makes sense and has meaning-reflects back on the foundations of being human: that human beings have to give meaning to the world. The world view of the animals is the counterpart of their instinctive life patterns: only on this instinctive level is the world clear to them. Humans, however, do not exist at this level of meaning, or if they do, then it is only temporary or partial. Children may be temporarily occupied with the problems of their organic reality, but soon they begin to act on and give significance to the world. 
In this labor of assigning significances, the child is not altogether free. I would like to point out the six most important limitations:

1. The human being has a body; this body is not only a springboard, but it is also a fetter; it becomes tired, requires nourishment; it finds itself in a particular place, etc.

2. The child is initially dependent, helpless in fact, and must reckon with his or her limited powers; that is, there are:

3. Other people present, who care for the child and raise the child, for whom the child must also account.

4. The child lives in a world which provides him or her with a ready-made structure of qualities that offers security; it serves the child in certain aspects and qualities, but it also may eventually restrain him.

5. There already is a past which supports the child but which may also limit the developmental possibilities for the child's life.

6. There is the next day, the future, with which each person must contend.

The child, this particular child, is not directly bound to a particular way of development although his possibilities in the double-sided process of creating form and meaning out of his being-in-the-world are limited as he eventually becomes what we will then call "this person." A process of "sense-making" takes place. I give to myself and to the world a sense of being, of existing. In this connection, however, there are various modes of "sense-making" or "meaning-giving."

First of all, there is the "open sense-making." This is the collection of interpretations that we build through our communion and contact with our fellow human beings. This is the sense-making that arises out of, and consists of, common agreements: the meaningful, heldin-common world of daily life.

There is also, in contrast, a non-obligatory sense-making. This form of meaning creation is not "bound" to the physical world, and yet it is not structureless. I refer here to the world of play. Through play we see how the things in this world need not have fixed meanings. That which in the "open sense-making" is a pencil now suddenly is a bridge, a road block, a soldier, or a house. Nevertheless, one can "play" only when one enters with play friends into the kind of sensemaking that belongs to the game. This sense-making is free only when viewed from the outside: that is, from the perspective of the "open sense-making." From the point of view of the child, it is realistic and connected to the world. Only the person who, for the purpose of play, accepts this meaning in exchange for his or her own reality presuppositions, can play with the child. When a child plays "bridge" with a pencil, it is a "bridge" only as long as the way back to "open sense-making" (ordinary shared reality) exists. When the pencil can no longer become just a pencil, then we enter the realm of 
illusion (nonsense) and we can no longer play with the child. To be sure, what is nonsense to us is for the other a manner of sense-making, albeit a very restricted one.

Thirdly, there is the "creative sense-making" of the artist. It constitutes its own coherent world. In this discussion we may be allowed to pass over this form of sense-making.

Finally, there is also what I would like to call a "personal sense-making." It consists of the ways and means by which I constitute myself as a person. I shape the world in my person in the sense that the "Iand-World" become a unified duality for me.

When we take note of the various barriers to the child's freedomhis body, his dependence, his fellow human beings, the "objective" world of things, his life history-together with the various modes of sense-making, then it becomes obvious how enormously complicated the work of assigning meanings to the world is for human beings. Then the nonsense of people hardly discourages us and the complexities and confusions of their ideas of human life become the normal showpiece of the world-more normal than a uniformly dictated world concept. And together we can plead patience for the many who seem to be not at all aware of the world. We must be mindful of the fact that within the various sense-making modes more than one possibility exists for the relationship of the "I" to the objective world and that, therefore, various intentional spheres of objective reality are possible.

We will now apply the preceding phenomenological explication to a thoroughly common, everyday example. We will choose a slipper. How many things can this slipper actually be? It can be a slipper; it can also be a hairy something upon which one can slobber. In the first instance, it is a simple object-of-use; in the second it is a purely sensual object-for-me. The child can also use the slipper as a hammer in order to pound a nail. In this case the slipper is no longer just an object-of-use; it is a used object: certain objective thing properties-here the hard heel-are chosen to fulfill a thinglike function directed toward another thing. It is therefore a used object but not an object-of-use whose complete properties are directed toward a certain proper use, in this case, as a slipper. But a child can choose a specific property of the slipper whose use is not thing-directed. The slipper could be used as a doll's cradle, for example. In this case, the slipper-become-cradle takes its meaning from the realm of the world of play and not from the common world as a tool directed toward accomplishing a task.

And the slipper can also lose itself in the background against which our actual life is lived. If this is the case, the slippèr is simply there and is almost an otherworldly thing; it has little actual significance in the life of this particular child. The slipper can also come to us as 
from a distance if it is presented, regarded, or treated as a sketched or painted object, or if it is presented as an art object itself. Or, the slipper can be a reminder, a symbol of our loved ones-the small child, the little brother who died. Or (again in another connection), it can be the slipper of the father, and the child realizes the connection. This slipper is a symbol of father, and the child says in his glance not "slipper" but "papa, papa" as if the slipper were pars pro toto. What a lot of things a slipper can be! And it can signify much more besides.

I would like to mention one more mode of being of an object: the socalled gift or present. When we give the usual vase (with or without flowers) as a wedding present, and the young bridal pair are already gleefully anticipating the day when their firstborn pulls the ugly thing from the table, then we can hardly say we have given a "gift." I call something like this a "present" because the French have a saying, "les petits cadeaux soutiennent l'amitié" (small presents maintain friendship). As we shall see, it is directly reversed with gifts: a present can make friendship, but love and friendship make gifts, even the smallest ones, possible.

The four-year-old child comes to her mother, who is busy with the newborn baby, and has a "treasure" in her hand. It is the tiny feather of a sparrow. "This is for little brother, because he is still so small." Now that is a true gift! It is not "le petit cadeau qui soutient l'amitie" but rather, here we see "l'amour qui soutient les petits cadeaux." This feather is a sign of a union of love. The feather is small - so be it: Isn't the little brother small too? But how delicate and soft the feather is! It almost makes the beholder delicate and soft too!

Whoever gives a gift (and not just a mere present) gives himself. $\mathrm{He}$ $i s$ the thing. And when someone gives his love silver, all the more so. When he really "gives" the "present," he himself becomes shiny and mirror-perfect, and for him his loved one becomes as bright and clear as a mirror. And when he gives her a diamond, he gives her the clear sparkle of her eyes and the purity of his and her love. In the present as gift, the giver gives himself. He gives something of himself. In the case of the present as cadeau, one gives something from the store, often merely just a suggestion from the salesperson.

The small child with her feather would be a miser if she had given her worthless object as a cadeau, a mere present. But she gave her present with all her heart and is therefore a rich, freegiving child, and the little feather is not a plain, meaningless, and worthless thing. It is a deep reality of the little child's heart and is perfectly filled with her subjective intentionality. "This little feather I will give to my feather-small brother." The thing itself steps far into the background - this fuzzy, worthless thing. Actually the thing is there 
only as a symbol of the love of the giver. It is hardly even a feather any longer; it is more like a hook upon which we hang our emotions. It would take only one more step for the psychologists to say that projection is involved here. "The object merely becomes the bearer of the subjective emotions." Whether projection or not, phenomenologically it is clear that the little feather fell onto the cultivated field of tender togetherness and came to signify a deep love and not just its trivial thinglike being.

We all know the peculiar appeal of things which is so important for children. Some aspects of a thing appeal to us, and the object speaks to us in a way that demands action: we must do something with it. So it was with the feather, and we are familiar with this appeal from Straus' notion of the pathic quality of the things of the world: the round calls for rolling, the thin for stretching, bending, and whipping, and so forth. I would now like to bring to attention another aspect of the invitational character of things and choose, as my example, a box.

Let us imagine that we give a child a box as a present. We are not giving her a cleverly folded piece of cardboard. We are, in fact, giving her a request, a problem to solve: what belongs in that box? The emptiness silently stares at us. It just can't remain that way. The child hears this silent voice very clearly. Before long, she has put something inside the box, or we suddenly find a little beggar beside us. "But what shall I put into it?" How wonderful it is when we give the child a small candy. Marvelous how the emptiness of the box vanishes, is dissipated by this one candy. The dissipation of emptiness depends on the request for action-a candy used to dispel the emptiness-for as long as it lasts. The candy soon begins to whisper promisingly to us. Which call will win? In all likelihood the box will soon be forgotten. Sometimes it will be empty, but sometimes a sticky lump will show that the child saw the box as what it is: a container and used as such. The child succumbed to the appeal of the thing.

To summarize: the human child has a world and she is together with this world, her own task. Her task is a meaning-giving, a sense-making work. In this task, she is not altogether free, and I have named five limits to her freedom.

In the context of these limits to freedom, these unyielding incorruptible facts, we find the body that is not a mere thing among the so-called things. It may well be that the things, the objects of the world, are incorruptible in their thinglike characteristics, but the sense-making process can attach an extraordinary number of different meanings to the same object as we have seen with the examples of the slipper and the box. In the case of the box, a peculiar possibility arose; something was there that really wasn't there: the empti- 
ness. And the emptiness of the box arises when the small candy, the last one, is taken away. And the emptiness vanishes when this one candy is put into the box again. We are dealing here with a possibility of the thing-world-emptiness-which is associated with this thing, but which is not a property of this thing. In the case of the gift, we saw how the things can be taken into the I-world of a person. In the case of the box, we learned how the thing itself reaches into the world beyond its limited properties.

Let us assume that the child is on this earth for the first time. She knows nothing about things. The things are intimately unknown. How does the child come to know the things?

Undoubtedly child psychology has taught us much about this topic, and it is unnecessary to summarize its findings. However, I would like to try to throw light on a completely different aspect of the meeting between the child and the world of things. We have already seen how a thing reaches into the "I" and the world. We now choose to examine a seldom analyzed connection among people. You will recall that the second limitation on the child's freedom in sense-making, her dependence on adults, and the closely related third limitation, that other people exist. Now the child's recognition of the world and her knowledge of the world are largely dependent on the help or influence of others. She learns many things only in situations in which her fellow humans are present. In fact, there are things that one can only make sense of in fellowship-the see-saw, for example. Only in imagination can one sit alone on a see-saw. It requires two people to make it work. The form of the object itself shows this up clearly: it has two seats-one to the left and one to the right of the fulcrum. The see-saw only works when there are two players who are together, each of them playing his or her part. Human communion is publicly decreed in the communion of these two players. The players are brought together through the object. I call this form of communion "conjoint-ness" (the state of being gathered in togetherness). There is no "thing-ness" attributable to the partner in this togetherness (and "togetherness" is a weak word in this context). I think of greetings, the moment in which two people "see" each other, or of every form of human being-together, however pleasant, in which this true sense of "being-together" is really not present. The see-saw accomplishes this total being-together. When there is no partner, then the see-saw is a lost opportunity, a demonstrable impossibility. So we find that here the object necessitates the second person. It does this quite concretely. There are many objects which have this referential character but where the referential character is not as concretely visible or experiential.

A ball shows us this quite clearly. As a rolling sphere it issues an immediate challenge to be handled: a provocation of the pathic or invitational character of the things of the world. That which rolls (is 
roll-able) demands to be rolled, kicked, or pushed. But let us push this ball away and what happens? Another person comes and pushes it back to us. That is the discovery of a possible reciprocity, a possible human mutuality which was not evident with the ball as immediately as it was with the see-saw. The ball plays with us as long as it bounces back, but once we push it some distance from us, then it sometimes brings a fellow human into our world.

Sometimes, however, this fellow human fails to step into our world of his own accord. We then need other people, our parents, to present the distant fellow human as an aspect of the object. For example, when the child, with dirt on his shoes, climbs onto a chair or onto the seat of the train car, then we shout at him, "Watch out! You're muddying the seat. Soon somebody will come and sit there!" Even if this somebody (or some thing) lived on a deserted island in a different time, now he (it) is called into our time frame-there are others who are coming now, or at a certain time.

And we shout at the child a thousand times, "Watch out! Don't break that!" What does it mean to be broken? If the dear God allows our dead grandmother in heaven to be young and to live again, then there is no need to get so upset when one uses daddy's special pen as a hammer. But that thing is supposed to stay as it is. And this is the point: it is supposed to stay whole like it was before, as it belonged to us, because it is a familiar part of our world. In this manner too, mother's plates and cups are to remain whole as they were before, as a part of mother's or father's or my world. But see here-a cunning property, a trick of the culture-as long as the plates and cups remain whole, they retain their particular object permanence. And so next year, the new uncle, who is just coming from abroad for the first time, can drink from the cup which belonged to the legendary great grandfather.

Through this encounter with things, we enter into the world of history and of the future. The things in the world of the child don't just show their own age, they make reference to.the lives and worlds of other people who are no longer with us or who are not yet with us. There is, of course, the materialistic or bourgeois fear and concern for furnishings and property. There is also, however, an invitation to address things in a language appropriate or respectful to the things, which then makes a proper contribution to social upbringing (socialization of the child).

"Others" are very important in this job of learning about things, and this is not only when the objects call us to be partners. Sometimes things are so supervised and so carefully interpreted by grown-ups that the child cannot help but learn through the encounter with things the various dimensions of human sense-making (for example, cooperation, the earlier times, our belongings from an ancient past, 
the continuity of then and now). Behind the things there is always a person, and he peers through them, as it were. This is seen especially clearly in tools. Tools are like amphibians-they serve two masters. They are of the thing-world and they are adapted to the human body as well. One can only make use of this amphibian when one is able to see beyond the purely organic form of things and understand something of the mechanical essence and qualities of things. That is, one has come to eavesdrop on the stones so that one can come to know how they will allow themselves to be sculpted.

But what of the things of nature? We were just speaking of stones. The things of nature are encountered in a world that has a different kind of freedom from the one near us at home. I am not speaking here of animals necessarily, which are especially interesting because they are always "doing" something-flying or running to and fro in my world, or giving their particular cry, or even licking my face. And plants also occupy a peculiar place. They are primarily represented through flowers, and yet so easily we wander over them as if they were merely gravel on the garden path. "Let's go pick flowers." We go pluck the garden as if it were a chicken. This is fun because one always "has" something which one has "taken" and which shows such nice colors. But how soon we forget the bouquet; how soon we forget the flowers lying on the street!

And yet, the world of nature is a realm of freedom-no less for the child who has learned to care for nature than for the city dweller who regards nature as an exercise yard or a garbage dump. Nature is a care-free world. The call of the things is a call to our freedom to be free. The beauty of nature is a later discovery; its dangers and delights are taken for granted by older people. The child, however, comes to know nature first as the place of freedom. One climbs the trees because they invite one to do so, as do the rocks and the cliffs. One plays in the sand, the water and the snow; one builds with stones, always because they invite one to do so. The flowing water, the swirling sand, and the snow that sticks together well, they speak a totally pathic dialect and entice us toward play. But soon the unspecified manipulation of formless materials must stop, and organization begins. Whoever wants to build something out of sand or snow or wants to put a bridge over a stream must come to reckon with the objective qualities of sand, snow, and water. Again the thing-world lures the organizing, the sense-making person, just as one is lured into a magic forest. In his profound human task of shaping, organizing, and sense-making, the human being advances ever farther into the thing-world. And there, only the voices of the things offer him support. As Bacon said, "here one rules only insofar as one submits to the thing."

But what does it mean to submit one's self to the things? Does it mean a loss of freedom, or slavery? Not at all! It signifies a victory. 
For whoever has come to understand how to put just three stones together in a swirling stream so that they stay together has changed the world. How mistaken is the adult, who, from the height of his maturity, smilingly belittles the sandcastle, the snowman, or the bridge as a triviality. These are actual and essential achievements of the human being because human beings have made form and meaning out of formlessness and meaninglessness. These achievements signify a step into the realm of the particulars of the reality of objects. They signify a renunciation of the more primitive freedom to leave things as they are-as when one leaves one's hand in the water in order to let the sand wash through the fingers. It signifies, in other words, growth: growth of the mind. Spiritual growth always signifies the renunciation of the more primitive freedom and security, too. For whoever leaves the familiar world risks something. He risks the possibility of his attempts running aground. He risks failure. Spiritual growth implies the renunciation of security. But this, again, presents a new beginning, a foundational security, one that begins to guide us. This last security, the one which is supposed to guide us when our first security leaves us, is a security for which we ourselves must carry, or learn to carry, the responsibility.

\section{Notes}

1. Translated and edited by Max van Manen and Peter Mueller. From M. J. Langeveld, Das Ding in der Welt des Kindes (in Studien zur Anthropologie der Kindes. Tübingen: Max Niemeyer Verlag, 1968). 